\title{
Reflets
}

Revue ontaroise d'intervention sociale et communautaire

\section{Bibliographie des articles Hors thème ou paru dans la section Aux études - 1995 à 2006}

Volume 13, numéro 1, 2007

La violence dans tous ses états

URI : https://id.erudit.org/iderudit/016821ar

DOI : https://doi.org/10.7202/016821ar

Aller au sommaire du numéro

Éditeur(s)

Reflets : Revue ontaroise d'intervention sociale et communautaire

ISSN

1203-4576 (imprimé)

1712-8498 (numérique)

Découvrir la revue

Citer ce document

(2007). Bibliographie des articles Hors thème ou paru dans la section Aux

études - 1995 à 2006. Reflets, 13(1), 221-221. https://doi.org/10.7202/016821ar

Tous droits réservés (C) Reflets : Revue ontaroise d'intervention sociale et communautaire, 2007
Ce document est protégé par la loi sur le droit d'auteur. L'utilisation des services d'Érudit (y compris la reproduction) est assujettie à sa politique d'utilisation que vous pouvez consulter en ligne.

https://apropos.erudit.org/fr/usagers/politique-dutilisation/ 


\section{Bibliographie des articles Hors thème ou paru dans la section Aux études - 1995 à 2006}

\section{Volume 5, numéro 1}

DENAULT, Marise (1999). «Malgré la rupture, la violence persiste... La violence conjugale et le harcèlement criminel ", printemps, 208-225.

\section{Volume 5, numéro 2}

MCKELLAR, Jocelyne (1999). "L'état de santé des personnes âgées francophones en Ontario ", automne, 290-306.

\section{Volume 6, numéro 1}

RIVETTE, Francine (2000). "L'usage abusif de substances toxiques par les femmes violentées : les effets d'une victimisation sociale », printemps, 232-249.

\section{Volume 7, numéro 1}

JOBIN, Marie Josée (2001). "Prostitution : de la théorie de l'étiquetage à la pratique du vécu. La Perception de cinq femmes qui font de la prostitution ", printemps, 206-228.

\section{Volume 7, numéro 2}

CARRIÈRE, Richard, KAUPPI, Carole et Herb NABIGON (2001). « Sondage auprès des diplômées et diplômées de l'École de service social de l’Université Laurentienne ", automne, 192-204.

NDIAYE, Lena D. (2001). "Le service social au Sénégal : recherche d'un sens ou histoire d'une réception ", automne, 172-191.

\section{Volume 9, numéro 1}

HASAN, Rachel, DROLET, Marie et Maryse PAQUIN (2003). « Les conduites violentes chez les enfants de trois à six ans : comprendre pour mieux intervenir ", printemps, 150-177. 